\title{
PENYIMPANGAN UNSUR KEAMBIGUAN DALAM TEKA-TEKI SUNDA
}

\author{
Hera Meganova Lyra* \\ Teddi Muhtadin \\ Taufik Ampera \\ hera.meganova.lyra@unpad.ac.id \\ Universitas Padjadjaran Universitas Padjadjaran \\ Universitas Padjadjaran
}

\begin{abstract}
This research describes the deviation of ambiguity element in Sundanese riddles. The research focuses on the linguistic matter regarding the deviation, characteristics, and functions of riddles in Sundanese society. The method used was descriptive method by using riddles structure theory of Young Ho (2002) and Ullmann (2012) and the folklore theory by Tarigan (1980). Through the theory of riddle structure, it is concluded that the deviation of ambiguity element in Sundanese riddles occurs in the levels of Phonology, Morphology, Syntax, and Semantics. From the folklore theory, it is determined that the characteristic of riddles in Sundanese society is the comparison of entertainment with the function of practicing cleverness.
\end{abstract}

Keywords: deviation, riddles, ambiguity, and Sundanese language

\begin{abstract}
Abstrak
Penelitian ini mendeskripsikan penyimpangan unsur keambiguan dalam tekateki Sunda. Adapun masalah yang dikaji meliputi penyimpangan unsur keambiguan dalam tataran linguistik, sifat dan fungsi teka-teki di masyarakat Sunda. Metode penelitian yang digunakan yaitu metode deskriptif dengan menggunakan analisisi teori struktur teka-teki Young Ho (2002) dan Ullmann (202) dan teori foklor Tarigan (1980). Melalui teori struktur teka-teki dihasilkan penyimpangan unsur keambiguan dalam teka-teki Sunda terjadi pada tataran fonologis, morfologis, sintaksis, dan semantik. Melalui teori foklor dapat ditentukan bahwa sifat teka-teki pada masyarakat Sunda merupakan pertandingan hiburan dengan fungsi untuk mengasah kepandaian.
\end{abstract}

Kata kunci: penyimpangan, teka-teki, ambiguitas, dan bahasa Sunda

\section{PENDAHULUAN}

Teka-teki merupakan permainan bahasa yang mengandung unsur pertanyaan dan harus diterka jawabannya. Unsur keambiguan merupakan unsur yang membedakan teka-teki dengan pertanyaan biasa. Tanpa unsur ini sebuah proposisi tidak bisa disebut teka-teki.

Seorang pembuat teka-teki perlu menyusun wacana teka-tekinya sedemikian rupa sehingga menggandung unsur ambigu. Unsur ini sengaja dibuat dengan maksud mengaburkan informasi. Semakin ambigu sebuah teka-teki biasanya akan semakin mampu menimbulkan keingintahuan sekaligus menarik perhatian untuk ditebak. Tidak mengherankan jika sering kali pertanyaan teka-teki terasa aneh, menggelikan, 
atau bahkan mengejutkan.

Pertanyaan:

Palu naon nu bisa ngomong?

'Palu apa yang bisa berbicara?'

Jawaban:

\section{Pa Lurah}

'Pa Lurah'

Pertanyaan teka-teki di atas secara gramatikal, struktur kalimatnya benar tetapi tidak logis secara semantis. Kalimat semacam itu disebut kalimat anomali. Palu merupakan benda mati yang biasa dipakai untuk memukul paku. Tentunya menyimpang dari kenormalan jika palu bisa berbicara. Hubungan antara palu 'palu', ngomong 'bicara' dan pa lurah 'pak lurah' adalah bukti keambiguan dalam sebuah teka-teki.

Menurut Young Ho (2002:96) unsur keambiguan dalam teka-teki dapat dilihat dari sudut pandang kebahasaan dan kontekstual. Unsur keambiguan dalam kebahasaan dapat dirinci berdasarkan tataran fonologis hingga semantis sedangkan keambiguan kontekstual mengacu pada hal-hal di luar kebahasaan dan dapat dilihat berdasarkan empiris yang bertautan dengan aspek sosial, politik, dan budaya.

Dalam bahasa Sunda teka-teki disebut dengan istilah tatarucingan. Selain tatarucingan, untuk teka-teki dikenal juga wawangsalan. Wawangsalan juga merupakan permainan bahasa yang menghendaki penerkaan atas jawabannya. Bedanya wawangsalan itu terdiri dari dua buah proposisi. Proposisi pertama disebut cangkang (jika meminjam istilah Young Ho bisa dikategorikan sebagai pembatas). Proposisi kedua disebut eusi (istilah Young Ho disebut dengan pembayang). Jawaban wawangsalan tersirat ada pada proposisi kedua 'eusi', biasanya berupa potongan suku kata atau kata. Untuk lebih jelasnya kita lihat contoh wawangsalan berikut di bawah ini.

$\begin{array}{ll}\text { Simpay rema beulit cinggir } & \text { cangkang } \\ \text { jari membelit kelingking } & \text { pembatas }\end{array}$

$\begin{array}{ll}\text { Ulah lali } \mathrm{ka} \text { sim abdi } & \text { eusi } \\ \text { jangan lupa pada saya } & \text { pembayang }\end{array}$

Jawaban: ali 'ali

Deskripsi pernyataan wawangsalan (proposisi ke-1) dibatasi pada sesuatu yang selalu membelit di jari tangan. Pembayang yang terdapat pada proposisi ke-2 merupakani clue 'petunjuk' untuk menerka jawabannya. Clue terdapat pada kata lali 'lupa', alih-alih dari jawaban ali 'ali'. 
Teka-teki Sunda dipilih sebagai objek dalam penelitian ini karena didasarkan pada sifat dari masyarakat Sunda yang cenderung humoris dalam kehidupannya. Kehumorisannya ini cenderung dimunculkan dalam kegiatan berteka-teki.

Teka-teki Sunda pernah dijadikan objek penelitian oleh Hermawan (2005). Penelitiannya berfokus pada teknik (cara mendeskripsikan pesan teka-teki), strategi penyajian, kontruksi, dan makna teka-teki. Kali ini penulis akan mencoba meneliti teka-teki Sunda dari sudut penyimpangan yang ditimbulkan unsur keambiguan dalam teka-teki. Selain itu, juga akan dicoba diteliti mengenai sifat dan fungsi teka-teki yang dihubungkan dengan masyarakat penuturnya.

Data teka-teki yang dideskripsikan dan dikaji dalam penelitian ini berasal dari data lisan. Data diambil dari informan yang berada di Kecamatan Jatinangor Kabupaten Sumedang pada tahun 2013. Informan bukan hanya penduduk pribumi tetapi bisa juga pendatang, terpenting informan itu berada di Kecamatan Jatinangor Kabupaten Sumedang. Data lisan ditranskrip menjadi data tulisan.

\section{LANDASAN TEORI}

\section{Definisi Teka-teki}

Pengertian teka-teki dalam Kamus Besar Bahasa Indonesia (1990:915) adalah (1) soal dsb yang berupa kalimat (cerita, gambar,dsb) yang dikemukakan secara samar-samar, biasanya untuk permainan atau untuk pengasah pikiran; (2) hal yang sulit memecahkannya (kurang terang, rahasia, dsb).

Young Ho (2002:77) memberikan pengertian teka-teki didasarkan pada bentuk dan cirinya adalah sebagai berikut:

1. Teka-teki berbentuk pertanyaan dan jawaban yang berupa satu wacana dialog.

2. Pertanyaaannya dapat dikemukakan, baik secara langsung maupun tidak langsung, lengkap ataupun tidak lengkap, tetapi harus memiliki unsur keambiguan kebahasaan atau unsur keambiguaan kontektual.

3. Dalam bentuk pertanyaan, penanya menangtang pendengar untuk mengenali dan mengidentifikasi topiknya karena deskripsi pertanyaan biasanya tampak tidak mungkin, kontradiktif, atau terlalu sederhana. Namun hal itu memiliki kesesuaian yang unik berkaitan dengan jawaban sehingga akhirnya jawaban dapat diterima pendengar atau penjawab.

4. Balasan responden dilakukan dalam bentuk verbal dan berorientasi pada penyelesaian atas proposisi yang diajukan.

Dengan berpatokan pada keempat hal tersebut di atas, maka dapat dikatakan bahwa teka-teki adalah sebuah bentuk tanya jawab berupa wacana dialog yang memiliki unsur keambiguan kebahasaan dan kontekstual dan antara pertanyaan dengan jawaban 
mempunyai kaitan sehingga dapat diterima oleh pendengar atau pembaca karena adanya kesesuaian yang unik di antaranya.

Sementara itu, Goerges dan Dundes (dalam Danandjaja, 2002:33) mendefinisikan teka-teki sebagai ungkapan lisan tradisional yang mengandung satu atau lebih unsur deskripsi dan sepasang di antaranya dapat saling bertentangan dan jawabannya harus diterka.

\section{Jenis Teka-Teki}

Goerges dan Dundes (lihat Danandjaja: 2002) membagi teka-teki dalam dua kategori umum, yakni: (1) teka-teki yang tidak bertentangan (nonoppositional riddles) dan teka-teki yang bertentangan (oppositional riddles). Teka-teki yang tidak bertentangan unsur-unsur pelukisanannya bersifat harfiah, yakni seperti yang tertulis (literal) atau kiasan (metaphorical). Jawaban dan pertanyaan adalah identik. Sebagai contoh: “Apa yang hidup di sungai?" yang merupakan pertanyaan suatu teka-teki; dan jawabannya adalah: " ikan”.

Keadaan akan menjadi lain pada teka-teki yang tidak bertentangan yang bersifat kiasan; karena referen dan topik unsur pelukisanannya berbeda. Contoh 'Apa itu dua baris kuda putih berbaris di atas bukit merah?' adalah topik teka-teki semacam ini, dengan 'sederet gigi di atas gusi' sebagai referennya. Dalam teka-teki macam ini, topim (kuda) dan referan (gigi) secara harfiah adalah berbeda.

Sedikitnya, menurut Georges dan Dundes, ada tiga macam pertentangan yang berbeda pada teka-teki bertentangan dengan tradisi lisan orang Inggris, yakni (1) kontradiksi yang berlawanan (antithetical contradictive); (2) kontradiksi yang mengurangi (privational contradictive); (3) kontradiksi yang menyebabkan (causal contradictive).

Suatu teka-teki baru dapat digolongkan ke dalam jenis teka-teki bertentangan yang bersifat antithetical contradictive, apabila hany salah satu dari sepasang unsur pelukisannya yang bertentanagn benar. Selanjutnya teka-teki yang bersifat antithetical contradictive ini dapat berupa dua macam. Macam pertama unsur kedua pasangan unsur pelukisannya mengingkari unsur kedua pasangan unsur pelukisannya mengingkari yang pertama. Macam kedua teka-teki bersifat antithetical contradictive ini adalah unsur kedua pasangan unsur pelukisannya tidak harus menyangkal (deny) unsur pertama, melainkan merupakan penguatan, walaupun dalam bentuk kontadiktif.

Suatu teka-teki baru dapat digolongkan ke dalam teka-teki bertentangan yang bersifat privational contradictive opposition, apabila unsur kedua dari sepasang unsur pelukisannya mengingkari suatu tanda (attribute) unsur pertama yang wajar atau logis. Contohnya adalah: 'Ia mempunyai tangan, tetapi tidak dapat memegang'. Jawabnya 
adalah jari-jari lonceng.

Suatu teka-teki dapat digolongkan ke dalam teka-teki bertentangan yang bersifat causal contradictive oposition, apabila bagian pasangan unsur pelukisannya mengingkari akibat wajar suatu perbuatan yang dilakukan oleh atau kepada benda yang terkandung dalam bagian pelukisan pertama. Bentuk teka-teki semacam ini setidaknya ada dua macam. Yang pertama adalah bagian kedua pasangan unsur pelukisannya secara eksplisit mengingkari akibat perbuatan yang terkandung di dalam unsur pelukisan pertama yang diharapkan atau wajar. Contohnya dari folklor mahasiswa Jakarta; 'Apa yang menuju ke Monas setiap hari, tetapi tidak meninggalkan jejak?' Jawabnya adalah 'Jalan Monas!' Macamlainnya adalah bahwa bagian kedua unsur pelukisan mengandung pernyataan yang sebaliknya dari apa yang diharapkan, sebagai akibat wajar perbuatan bagian pertama. Sebagai contohnya adalah teka-teki mahsiswa Jakarta yang berbunyi:'Apa yang biarpun dikunci di dalam rumh, dapat juga keluar?' Jawabnya dalah;'Api kebakaran!'

Archer Taylor di dalam bukunya yang berjudul English Riddles from Oral Tradition (1951), telah membedakan teka-teki dalam dua golongan umum, yakni: (1) teka-teki yang sesungguhnya (true riddle) dan (2) teka-teki yang tergolong bentiuk lainnya. Perbedaannya terletak pada hubungan yang ada pada jawab dengan pertanyannya, sehingga masih dapat dipecahkan dengan logika.

Febriyanti, dkk. (2014) menjabarkan jenis teka-teki berdasarkan wujudnya. Berdasarkan wujudnya teka-teki dibedakan atas: (1) teka-teki metaforik, (2) teka-teki simbolik filosofis, (3) teka-teki akronimik, dan (4) teka-teki pornografi.

\section{Sifat dan Fungsi Teka-teki}

Menurut Tarigan (1980: 12-13) teka-teki mempunyai beberapa sifat, yakni: (1) merupakan pertandingan hiburan, (2) pendagogis, (3) struktur yang merupakan wacana dialog yang unik, (4) menciptakan ungkapan bahasa yang estetik, dan (5) sindiran.

Sesuai dengan sifatnya, fungsi teka-teki berbeda-beda tergantung pada masyarakatnya dan berubah terus sesuai dengan perkembangan atau perubahan masyarakat (Young Ho, 2002:73; Danandjaja, 2002: 45; Asmirata, ). Hal tersebut didasari karena teka-teki merupakan salah satu jenis foklor dari sekelompok orang yang memiliki ciri-ciri pengenalan fisik, sosial, budaya yang sama. Fungsi teka-teki yaitu: (1) untuk menguji kepandaian atau mengasah otak, (2) untuk meramal, (3) sebagai bagian upacara perkawinan, (4) untuk mengisi waktu pada saat bergadang menjaga jenazah, (5) untuk dapat melibihi orang lain, dan (6) untuk menimbulkan tenaga gaib.

Fungsi pertama untuk menguji 'kepandaian' seseorang. Kami menyebut 
kepandaian seseorang dan bukan kecerdasan seseorang karena dalam kenyataan banyak teka-teki tidak dapat dijawab dengan daya berpikir saja, melainkan jawabannya harus diketahui dahulu. Memang untuk menguasai pengetahuan suatu koleksi tekateki, kita bukan saja harus mengetahui pertanyaannya, melainkan juga harus sekaligus mengetahui jawabannya. Hal ini disebabkan kebanyakan yang dilukiskan di dalam pertanyaan bersifat metaforikal (kiasan). Akibatnya hampir tidak mungkin bagi seorang untuk dapat menjawab suatu teka-teki tanpa pernah mengathui terlebih dahulu jawabannya yang tepat. Oleh karena itu, orang yang paling banyak mengetahui tekateki akan mendapat kepuasan, karena akan terkenal sebagai orang yang berpengetahuan luas mengenai folklor. Hal ini akan menjadi lebih penting lagi apabila ia berdiam di dalam masyarakat tradisional.

Fungsi kedua untuk meramal (divination). Istilah adivinanza untuk teka-teki, di dalam bahasa Spanyol, berasal dari kata latin divinatio, yang berarti meramalkan kejadian yang akan datang atau yang belum diketahui. Jadi rupanya dahulu teka-teki di Spanyol juga berfungsi utnuk meramalkan sesuatu hal. Di negara Cina Kuno memang teka-teki juga dipergunakan untuk meramalkan suatu hal. Di Jawa Tengah dahulu kala juga demikian. Buktinya ramalan Jayabaya pada hakekatnya adalah merupakan teka-teki yang harus diterka. Sebagi contoh misalnya, masa pendudukan tentara Dai Nipon di Jawa dikatakan hanya seumur jagung (yang dalam kenyataannya selama tiga setengah tahun).

Berbeda dengan Tarigan dan Yong Ho, Febriyanti, dkk. (2014) menyatakan sesuai dengan konteks budaya, teka-teki berfungsi sebagai (1) media pendidikan nilai budaya, (2) media hiburan anak-anak saat bermain, (3) media pendukung pertunjukan, (4) sarana untuk menciptakan suasana humoris, dan (5) media komunikasi sehari-hari.

\section{Unsur Keambiguan}

Menurut Ullmann (2012) keambiguan adalah kegandaan makna. Kondisi ini ditimbulkan oleh faktor fonetik, faktor gramatikal, dan faktor leksikal. Faktor fonetik berhubungan satuan akustik tutur dalam satuan helaan nafas. Faktor gramatikal berhubungan dengan pembentukan kata dan frasa, sedangkan faktor leksikal berhubungan dengan sebuah kata bisa mempunyai berbagai pengertian (196-200).

Pernyataan Ullmann tersebut di atas sejalan dengan pandangan Young Ho (2002:85) yang menyatakan unsur keambiguan yang tersirat di dalam deskripsi informasi dapat dibagi menjadi dua, yaitu :

1. Unsur keambiguan kebahasaan

Yang dimaksud dengan unsur kebahasaan ialah satuan bahan yang menentukan keambiguan di dalam informasi yang diberikan oleh unsur-unsur yang 
dikemukakan dalam informasi, yang terdapat pada tataran fonologis, morfologis, sintaksis, dan semantis yang ditinjau dari segi struktural.

2. Unsur keambiguan kontekstual

Mengacu pada hal-hal di luar kebahasaandan dapat dilihat berdasarkan empiris yang bertautan dengan aspek sosial, politik, dan budaya. Konteks ini muncul karena adanya perhatian, kejenuhan, atau sikap frustasi masyarakat atas suatu peristiwa, keadaan tertentu, dan kekesalan terhadap tokoh tertentu yang menjadi tokoh masyarakat.

\section{Unsur Kebahasaan}

Bahasa terdiri atas beberapa unsur. Unsur yang dimaksud mulai dari tata urutan yang paling kecil, yaitu bunyi bahasa sampai pada urutan yang lebih besar, yaitu wacana. Tiap unsur tersebut memiliki sistem tersendiri yang dapat dikaji secara khusus, dibidangi oleh ilmu yang berbeda. Bunyi bahasa dibidangi oleh fonologi, tata bentuk yang menyangkut kata dan pembentukkannya dibidangi oleh morfologi, tata kalimat dibidangi oleh sintaksis dan makna dibidangi oleh semantik. Dalam memaparkan teori unsur kebahasaan, penulis mempertimbangkan teori yang dikemukakan oleh Djajasudarma (2013).

\section{Fonologi}

Fonologi adalah ilmu yang mempelajari fonem atau dikatakan pula fonologi adalah cabang ilmu bahasa ilmu bahasa yang mempelajari bunyi-bunyi yang berfungsi. Dikatakan berfungsi karena tidak semua bunyi dalam ucapan (yang dihasilkan) memiliki makna atau menghasilkan bunyi bahasa. Fonologi dibagi ke dalam dua cabang disiplin ilmu yaitu fonetik dan fonemik. Fonetik mempelajari bagaimana bunyi ujaran dihasilkan alat ucap manusia sedangkan fonemik mempelajari bunyi ujaran yang berfungsi membedakan arti 'fonem'. Bahasa Sunda memiliki fonem segmental dan suprasegmental. Fonem segmental: fonem vokal, konsonan, dan diftong. Fonem suprasegmental: nada, tempo, dan tekanan.

\section{Morfologi}

Morfologi adalah ilmu yang mempelajari morfem dan bagaimana morfemmorfem tersebut dibentuk menjadi kata atau morfem komplek. Morfem sendiri merupakan satuan bunyi bahasa yang terkecil yang mengandung arti dan ikut mendukung arti. Etimologi morfologi dari bahasa Yunani morph 'bentuk' atau 'struktur' dan logos 'ilmu'. Dikatakan pula morfologi adalah ilmu bentuk (struktur) kata atau tata bentuk kata. Jadi yang menjadi objek kajian morfologi adalah morfem atau kata. 


\section{Sintaksis}

Kata sintaksis berasal dari bahasa Yunani sun 'dengan' dan tattein 'menempatkan'. Istilah tersebut secara etimologi berarti menempatkan bersama-sama kata-kata menjadi kelompok kata atau kalimat dan kelompok-kelompok kata menjadi kalimat. Bidang sintaksis menyelidiki semua hubungan antarkata dan antar kelompok kata. Yang menjadi objek sintaksis adalah frase, klausa dan kalimat. Frase adalah unsur sintaksis yang terdiri atas dua unsur atau lebih yang tidak predikatif, contohnya: baju hitam. Klausa adalah unsur bahasa yang terdiri atas dua unsur atau lebih dan bersifat predikatif (sekurang-kurangnya memiliki satu predikat), contohnya baju itu hitam. Kalimat merupakan tatran yang lebih luas dari klausa. Disamping itu kalimat disertai dengan adanya intonasi, contohnya: Baju itu hitam.

\section{Semantik}

Semantik berarti teori makna atau teori arti. Makna dibedakan atas dua, yaitu makna leksikal dan makna gramatikal. Makna leksdikal adlah makna yang sebenarnya, makna yang terdapat dalam kamus sedangkan makna gramatikal adalah makna yang ditentukan oleh struktur.

\section{METODE PENELITIAN}

Metode penelitian yang digunakan dalam penelitian ini adalah metode deskriptif. Penggunaan metode deskriptif dipertimbangkan atas pemusatan perhatian pada ciri-ciri dan sifat-sifat data bahasa secara alami sehingga dihasilkan pemerian data bahasa yang aktual untuk dapat dianalisis (lihat Djajasudarma, 1993).

Langkah-langkah yang penulis lakukan dalam penelitian ini adalah:

1) melakukan studi pustaka untuk mendapatkan teori yang berhubungan dengan masalah yang diteliti;

2) pengumpulan data, dengan cara menggunakan teknik perekaman, pencatatan dan pengkartuan (data tertulis). Dilakukan melalui tahap:

a) merekam data teka-teki sunda dari informan; informan bukan hanya penduduk

Kecamatan Jatinangor tetapi juga pendatang, yang penting informan tersebut tinggal di Kecamatan Jatinangor pada waktu pemupuan data dilakukan. Lokasi pemupuan di kampus Universitas Padjadjaran, Desa Jatinangor, Desa Sayang, dan Desa Cibeusi. Lokasi tersebut dipertimbangan mengingat pada lokasi tersebut tatarucingan menjadi obrolan hiburan sehari-hari.

b) mentransliterasi data ke dalam kartu data;

3) pengklasifikasian data; 
4) penganalisisan data dengan teori yang ada;

5) penyimpulan hasil penelitian sebagai jawaban terhadap masalah yang diteliti.

Metode kajian yang digunakan dalam penelitian ini adalah metode kajian distribusional, yaitu suatu kajian yang unsur-unsur penentunya terdapat dalam bahasa itu sendiri (lihat Djajasudarma, 2010). Teknik kajian yang digunakan adalah teknik bagi unsur langsung, yaitu membagi satuan bahasa yang dikaji secara langsung dengan memerikan istilah-istilah gramatik sesuai penentu unsur bahasa tersebut.

\section{HASIL DAN PEMBAHASAN}

Analisis data dalam penelitian ini mencakup dua hal, yaitu analisis penyimpangan unsur keambiguan serta analisis sifat dan fungsi teka-teki Sunda. Unsur keambiguan teka-teki menghasilkan penyimpangan pada tataran fonologis, morfologis, sintaksis, dan semantik. Dalam tataran fonologis, penyimpangan terjadi pada permainan bunyi lafal. Dalam tataran morfologis, penyimpangan terjadi pada bentuk kata yang berubah menjadi bagian suku kata dalam jawabannya. Begitu juga dalam tataran sintaksis, unsur ambigu yang berwujud kata berubah menjadi frase pada jawabannya. Pada tataran semantik penyimpangan muncul karena makna yang dimanifulasi.

\section{Penyimpangan Unsur Keambiguan dalam Teka-teki Sunda}

Penyimpangan unsur keambinguan dalam teka-teki Sunda meliputi penyimpangan pada tataran fonologis, morfologis, sintaksis, dan semantik. Penyimpangan fonologis terjadi dengan memanfaatkan bunyi lafal sebuah bahasa, penyimpangan morfologis terjadi dalam memafaatkan pembentukan kata, penyimpangan sintaksis terjadi dalam memanfaatkan pembentukan frasa, dan penyimpangan semantik terjadi dengan memanfaatkan permainan makna. Secara rinci penyimpangan pada tataran-tataran itu akan dijelaskan di bawah ini.

\section{Penyimpangan Unsur Keambiguan pada Tataran Fonologis}

Penyimpang unsur keambiguan teka-teki Sunda pada tataran fonologis cenderung memanfaatkan permainan bunyi sebagai unsur manifulasinya. Permainan bunyi tersebut memanfaatkan manifulasi lafal bahasa Arab, bahasa Jepang, dan bahasa Cina.

\section{(a) Permainan Fonetis Lafal Bahasa Arab}

Yang menjadi keunikan fonetis dari bahasa Arab salahsatunya adalah kuantitas pelafalan panjang-pendeknya sebuah fonem. Dalam bahasa Arab dikenal pelafalan satu harkat sampai tujuh harkat. Fonetis pelafalan ini yang kemudian dimanifulasi 
dalam teka-teki Sunda.

Pertanyaan:

Naon bahasa Arabna kopeah?

'Apa bahasa Arabna kopeah peci?'

Jawaban:

Wadaah huluu

'wadah kepala'

Teka-teki di atas mengalami penyimpangan unsur keambiguan pada tataran fonetis. Permainan bunyi lafal dijadikan kunci keambiguan. Jawaban teka-teki yang tidak sesuai dengan pertanyaan yang dikemukakan menjadi sah-sah saja. Jawaban teka-teki di atas seharusnya dalam kaidah kosakata bahasa Arab. Akan tetapi, karena ini merupakan tatarucingan, jawaban wadaah huluu 'wadah kepala' menjadi benar dan berkesan menggelikan. Bunyi khas (logat) dan sistem harkat dalam bahasa Arab dimanfaatkan menjadi unsur penyimpang.

\section{(b) Permainan Fonetis Lafal Bahasa Cina}

Orang Cina di Indonesia dikenali cenderung melafalkan kata dengan lafal cadel. Keadaan tersebut dimanfaatkan untuk memanufulasi pertanyaan dalam teka-teki Sunda seperti di bawah ini.

Pertanyaan:

Monyet supaya teu lepas naon bahasa Cinana?

'Monyet supaya tidak lepas apa bahasa Cinanya?'

Jawaban:

Cing ulang cangcang.

'kita ikat kakinya'

Dalam teka-teki atas, jawaban dari pertanyaan yang diajukan jika dilihat secara gramatikal dan semantiknya adalah benar. Hanya saja, karena mengejar clue bahasa Cina terjadi penyimpangan pada pelafalan jawaban. Jawaban yang seharusnya dijawab cing urang cangcang 'kita ikat kakinya' menjadi dilafalkan cadel cing ulang cangcang seperti halnya jika orang Cina berkata dengan kecadelannya.

\section{(c) Permainan Fonetis Lafal Bahasa Jepang}

Penyimpangan keambinguan dengan memanfaatkan permainan fonetis lapal bahasa Jepang terdapat pada teka-teki di bawah ini.

Pertanyaan:

Teu boga duit bahasa Jepangna naon? 
'tidak punya uang, apa bahasa Jepangnya?

Jawaban:

Sakurata

'saku rata'

Pelafalal bunyi bunga khas negara Jepang, sakura, dimanipulasikan dengan ditambah silabe ta untuk menjawab pertanyaan bahasa Jepangnya tidak punya uang. Sakurata menggambarkan keadaan tidak punya uang, saku akan terlihat atau teraba rata karena kosong tidak terisi lembaran uang.

\section{Penyimpangan Unsur Keambiguan pada Tataran Morfologis}

Penyimpangan unsur keambiguan pada tataran morfologis cenderung muncul pada bentuk kata. Biasanya dalam pembayang teka-teki ada satu kata yang menjadi unsur penyimpang. Unsur penyimpang yang berbentuk kata itu akan berubah menjadi bagian kata (suku kata) dalam jawabannya. Untuk lebih jelasnya kita lihat contoh di bawah ini.

Pertanyaan:

Hudang sare cari naon?

'Bangun tidur cari apa?'

Jawaban:

Carileuhan

'Bertahi mata'

Kata cari pada pembayang teka-teki di atas merupakan unsur ambigu. Kata cari tersebut bukanlah kata cari dalam konteks bahasa Indonesia melainkan penggalan dua suku kata pertama dari jawaban yang dimaksud carileuhan 'ada tahi matanya' (ca-ri-leuh-an).

Pertanyaan:

Papan naon nu matak rieut jeung hideung kana awak?

'Papan apa yang membuat pusing dan hitam pada tubuh?'

Jawaban:

\section{Papanasan}

'berpanas-panas'

Papan adalah bahan bangunan, tentunya tidak mempunyai hubungan dengan warna tubuh manusia. Papan yang dimaksud pada pembayang teka-teki di atas merupakan bagian penggalan kata dari jawaban yang dimaksud papanasan 'berpanaspanasan'. Dengan berpanas-panasan, kulit seseorang bisa menjadi hitam dan kepala menjadi pusing.

Pertanyaan: 


\section{Minyak naon nu nuduhkeun jalan?}

“Minyak apa yang menunjukkan jalan?'

Jawaban:

\section{Jalantah}

'Jelantah'

Tah sebagai kata ganti penunjuk dalam bahasa Sunda biasanya diletakan di awal kata yang ditunjuknya. Misal tah bawa 'bawa ini'. Tah yang bergabung dengang kata jalan dalam jalantah terletak diakhir kata. Jalantah 'jelantah' pada teka-teki di atas bukan merupakan kata ganti penunjuk tetapi silabe ketiga pada kata ja-lan-tah. Karena ini teka-teki, menjadi hal yang sah-sah saja dalam pengucapan kata jalantah antara jalan dan suku kata tah menggunakan jeda jalan' tah yang berarti jalan ini.

\section{Penyimpangan Unsur Keambiguan pada Tataran Sintaksis}

Selain permainan bunyi dan suku kata (bagian dari kata), dalam teka-teki juga sering digunakan unsur frasa yang merupakan satuan sintaksis.

Pertanyaan:

Paku naon nu bisa lempang?

'Paku apa yang bisa berjalan?'

Jawaban:

Ра Кичu

'Pak Lurah'

Paku dipakai sebagai pasak. Paku tidak bisa berjalan. Pada sebagian masyarakat Jawa Barat, jabatan kepala desa diberi nama kuwu (lurah). Lurah laki-laki dipanggilnya $P a$ Kuwu. Panggilan ini biasanya disebutkan dengan cepat sehingga tidak terasa lagi pemisahan antara $P a$ dan Kuwu tetapi sebagai Pakuwu saja.

Pertanyaan:

Tukang naon nu sok jejengkean?

'Tukang apa yang selalu berjinjit'

Jawaban:

\section{Tukang teuing}

'terlalu belakang'

Kata tukang pada teka-teki di atas bukan merujuk pada jenis pekerjaan seperti halnya tukang cendol atau tukang beca melainkan pada keadaan posisi terlalu belakang (tukang teuing). Ketika kita berada dalam posisi di belakang maka untuk dapat melihat ke depan, kita harus selalu berjinjit jejengkean.

Pertanyaan:

Ari ningali sipat jelema tina naonna? 
'Kalau melihat sipat manusia dari apanya?'

Jawaban:

Tina halisna

'Dari alisnya'

Sipat yang dimaksud pada teka-teki di atas bukanlah sifat dalam arti watak seseorang tetapi sipat dalam arti riasan. Sipat digunakan di halis 'alis', karena itu jika ingin melihat sipat seseorang maka lihatlah halis 'alisnya'. Apakan dia memakai sipat atau tidak.

Pertanyaan:

Angka naon anu sok ngelek, ngajingjing, nyuhun?

'Angka apa yang suka menenteng, menjinjing, memikul ?

Jawaban:

Angka ribung

'Repot membawa barang'

Yang dimaksud angka pada teka-teki di atas bukan angka dalam arti yang sebenarnya tetapi menunjuk pada suatu aktivitas seseorang yang melakukan kegiatan menjingjing, menjungjung, dan menggendong secara bersamaan. Dalam bahasa Sunda orang yang melakukan aktivitas tersebut disebut dalam keaadaan angkaribung 'repot membawa banyak barang'.

\section{Penyimpangan Unsur Keambiguan pada Tataran Semantis}

Pada tataran semantis unsur keambiguan metafora sering digunakan. Unsur keambiguan itu timbul karena sejumlah benda, hal, dan konsep manusia tidak dapat ditandai secra lengkap dengan hanya bunyi dan tanda bahasa. Penyimpangan keambiguan dengan bentuk metafora adalah memanfaatkan kemiripan bentuk kata namun dari segi makna kata itu sangat berjauhan. Contohnya adalah sebagai berikut:

Pertanyaan:

Aki-aki ragrag sila

'kakek-kakek jatuh bersila'

Jawaban:

Tai munding

'kotoran kerbau'

Aki-aki 'kakek' ialah orang yang sudah sangat tua, dianggap kurang dalam beraktivitas, kegiatannya hanya berdiam diri. Rumput yang dimakan kerbau dianggap cukup lama berada dalam perut kerbau, sudah tidak berguna dan dibuang. Apabila kerbau berak, kotorannya jatuh bertumpuk dan inilah yang disamakan dengan bersila.

Pertanyaan: 
Batu wulung sagede muncang asup munding tujuh rakit.

'Batu sebesar biji kemiri bisa memuat kerbau tujuh pasang'

Jawaban:

Bulan

Bulan

Batu wulung artinya batu yang bercahaya mewakili bulan. Bulan dimetaforkan sebagai muncang 'kemiri' yang bisa menanpung kerbau tujuh pasang.

Pertanyaan:

Nu ti luhur entod-entodan, nu ti handap melendung.

'Yang di atas bergoyang-goyang yang di bawah kembung.'

Jawaban:

Ngompa

'Memompa'

Yang dimaksud nu ti luhur 'yang di atas' adalah pompa, nu ti handap 'yang di bawah adalah ban (sepeda). Orang yang memompa ban membuat gerakan ke atas ke bawah untuk menekan anak pompa dan dengan demikian ban yang dipompa itu menjadi melendung 'gembung'.

\section{Sifat dan Fungsi Teka-teki Sunda}

Jika melihat teori yang dikemukakan oleh Tarigan (1980: 12-13) teka-teki mempunyai beberapa sifat, yakni: (1) merupakan pertandingan hiburan, (2) pendagogis, (3) struktur yang merupakan wacana dialog yang unik, (4) menciptakan ungkapan bahasa yang estetik, dan (5) sindiran. Dari kelima sifat tersebut sifat pertandingan hiburan cenderung digunakan oleh masyarakat Jatinangor dalam berteka-teki. Biasanya teka-teki dimunculkan pada waktu santai.

Sesuai dengan sifatnya, fungsi teka-teki pada masyarakat Kecamatan Jatinangor Kabupaten Sumedang berfungsi untuk menguji kepandaian atau untuk mengasah otak. Kami menyebut kepandaian seseorang dan bukan kecerdasan seseorang karena dalam kenyataan banyak teka-teki tidak dapat dijawab dengan daya berpikir saja, melainkan jawabannya harus diketahui dahulu. Memang untuk menguasai pengetahuan suatu koleksi teka-teki, kita bukan saja harus mengetahui pertanyaannya, melainkan juga harus mengetahui jawabannya. Hal ini disebabkan pelukisan proposi pertanyaan bersifat metaforikal (kiasan). Akibatnya hampir tidak mungkin bagi seorang untuk dapat menjawab suatu teka-teki tanpa pernah mengetahui terlebih dahulu jawabannya yang tepat. 


\section{SIMPULAN}

Unsur keambiguan dalam teka-teki Sunda menghasilkan penyimpangan pada tataran kebahasaan yang meliputi tataran fonologis (penyimpangan dalam permainan bunyi), tataran morfologis (penyimpangan dalam bentuk kata), tataran sintaksis (penyimpangan dalam bentuk frase), dan tataran semantis (penyimpangan dalam bentuk metafora). Sifat pertandingan hiburan cenderung dipergunakan oleh masyarakat Jatinangor dalam berteka-teki. Teka-teki pada masyarakat Kecamatan Jatinangor Kabupaten Sumedang berfungsi untuk menguji kepandaian atau untuk mengasah otak.

\section{DAFTAR PUSTAKA}

Asmarita, dkk. (2014). "Teka-teki Masyarakat Melayu Kecamatan Sungai Laur Kabupaten Ketapang (Analisis Struktur, Makna, dan Fungsi)" dalam Jurnal Pendidikan dan Pembelajaran. Volume 3, No 11 (2014).http://jurnal.untan. ac.id/indx.php/jpdpb/article/view/ [08 Mei 2018]

Coolsma, S. (1985). Tatabahasa Sunda. Jakarta: Djambatan.

Danandjaja, James. (2002). Foklor Indonesia. Jakarta: PT Pustaka Utama.

Djajasudarma, T. Fatimah. (1992). Semantik 1. Pengantar ke Arah Ilmu Makna. Bandung: Eresco.

Djajasudarma, T. Fatimah. (2010). Metode Linguistik Ancangan Metode Penelitian dan Kajian. Bandung: Refika Aditama.

Djajasudarma, T. Fatimah. (2013). Fonologi dan Gramatika Sunda. Bandung: Refika Aditama.

Febriyanti, dkk. (2014). "Teka-teki dalam Tradisi Lisan Madura; Kajian Etnografi”. tersedia dalam http://repository.unej.ac.id/bitstream/handle/123456789/64219/ YURISTIKA\%20FEBRIYANTI.pdf? sequence=1 [08 Mei 2018]

Hermawan, Yuki. (2005). Tatarucingan Teka-Teki Sunda'. Skripsi. Fakultas Sastra Universitas Padjajaran.

Tarigan, Hendri Guntur. (1980). Hutinta Ni Simalungun (Teka-teki Simalungun). Jakarta. Balai Pustaka.

Ullmann, Stephen (2012). Pengantar Linguistik. Cetakan ke-4. (Diadaptasi oleh Sumarsono). Yogyakarta: Pustaka Pelajar.

Young Ho, Im. (2002). Gejala Unsur Keambiguan dalam Wacana Teka-teki. Jurnal ATL No 8 Vol. 7, Desember 2002. 